\title{
Prevalence and Molecular Characterization of Cysticercus tenuicollis Isolated from Some Intermediate Host in Kurdistan-Iraq
}

\author{
Abdullah Ahmed Hama \\ Medical Laboratory Department \\ Technical College of Health \\ Sulaimani Polytechnic university \\ Sulaimani, Iraq \\ Research Center/ Sulaimani Polytechnic university \\ abdullah.hama@spu.edu.iq \\ Awaz M. Salih \\ Research Center, Sulaimani Polytechnic university \\ General Directorate of Health in Sulaimani \\ Sulaimani, Iraq \\ Awaz.salih@yahoo.com
}

\author{
Rostam Hama Zorab \\ Directorate of Veterinary in Sulaimani \\ Sulaimani, Iraq \\ rostamhama@gmail.com
}

\author{
Fatima Mohammed Ali \\ Research Center | Nursing department \\ Technical Institute of Sulaimani \\ Sulaimani Polytechnic university \\ Sulaimani, Iraq \\ Fatimah.Ali@spu.edu.iq
}

\author{
Amer Abdullah Hassan \\ Medical Laboratory Department | Research Center \\ Technical college of Health \\ Sulaimani Polytechnic university \\ Sulaimani, Iraq \\ Amer..hassan@spu.edu.iq
}

Abstract: Cysticercus tenuicollis (C. tenuicollis) is the larval stage infection of Taenia hydatigena, a common tapeworm of dogs and other Canidae, which has a wide range of intermediate hosts including sheep, goat, cattle, deer, camel, horse, human and other wild ruminants, the disease spreads through a contaminated water, soil and food with feces of infected dogs or other carnivores, $T$. hydatigena lives in the intestinal of the definitive host (carnivores) and excretes a huge number of eggs with feces daily. The present study conducted to determine the prevalence rate and molecular characterization of $C$. tenuicollis among sheep and goats in Sulaimani province. A total of 14088 slaughtered animals were inspected postmortem from the new Sulaimani abattoir comprise, which involves 13395 sheep and 693 goats. The selected cysts were preserved in $70 \%$ Ethanol for DNA extraction and molecular study, The mt-CO1 gene was amplified with a conventional polymerase chain reaction (PCR), the PCR product purified and DNA sequencing for reverse and forward strands was determined by a genetic analyzer, the obtained sequences aligned with the DNA sequences of T. hydatigena in Iran, Turkey, and Palestine, which deposited in GenBank under the following accession number (JQ710588), (JN827307) and (KM032284) respectively. The prevalence rate of C. tenuicollis was $2.63 \%$ in sheep and $2.58 \%$ in goats. This result shows no significant differences of $\boldsymbol{C}$. tenuicollis between sheep and goats $(p>0.05)$. The nucleotide sequence alignment of cytochrome oxidase subunit 1 (CO 1) gene revealed that the amplified DNA fragment belongs to Taenia hydatigena and Echinococcus granulosus and the nucleotide sequences of $T$. hydatigena deposited in GenBank under accession number (MH638348). This finding concludes that the amplification of mt-CO1 gene cannot be depended on discriminate hydatid cyst and $C$. tenuicollis while the partial DNA sequences of the mt-
CO1 gene are significantly valuable to differentiate $C$. tenuicollis from hydatid cyst, which is completely different in the pathology and control.

Keywords: Cysticercus tenuicollis, Taenia hydatigena, $m t$-CO1, DNA, Molecular marker.

\section{INTRODUCTION}

Taenia hydatigena is a cestode of the family Taeniidae, the adult stage of the parasite lives in the intestine of dogs and other Canidae (definitive host), while the larval stage, which is called metacestode (Cysticercus tenuicollis) develops and residing in domestic and wild mammalians (intermediate hosts), the cyst is developed as fluid-filled larvae in tissues [1, 2]. The adult bladder worm is a large thin, measure about $75-500 \mathrm{~cm}$ and is mostly called a slender thin worm [3]. The life cycle of $T$. hydatigena is indirect and required both definitive and intermediate hosts to complete its life cycle, adult worm lives in the small intestine of dogs, wolves, jackals, and foxes, the gravid segments are detached and eggs are expelled out and spread in the environment, the eggs will contaminate soil, grass, water, and vegetables. Eggs transmit to the intermediate hosts when it is eaten with plants or grasses. The egg will be hatched after ingestion and the hexacanth embryo penetrates the intestinal wall and then enters the blood circulation to reach the liver and another organ. Most of the embryo leaves the liver and they enter the peritoneal cavity to grow and develop to Cysticercus tenuicollis.

The definitive host becomes infected when fed on infected animal's offals. The scolex evaginates in the small intestine and attaches to the mucosa, then grows to an adult in 51days post-infection [4]

Metacestode (C. tenuicollis) is a cyst loosely filled with transparent fluid, with size varies from one $\mathrm{cm}$ up to seven $\mathrm{cm}$, and long necks which are usually found 
attached to the omentum, mesentery, and sometimes on the liver surface, particularly among the sheep and goat; however, unusual locations of $C$. tenuicollis have been described as the lungs, kidneys, brain, ovaries, uterine tubes, uterus, cervix, and vagina [5, 6]. Tenuicollosis is responsible for a high degree of morbidity and mortality in livestock and particularly the domestic animal; sheep and goat [7], it is frequently associated with hemorrhagic tracts of the liver in acute cases [8]. In slaughter animals, it has an important economic loss due to the condemnation of offal's containing larvae of $T$. hydatigena [9]. The metacestode may serve as a predisposing cause to black disease or may lead to acute traumatic hepatitis as well as a contributory agent of peritonitis [10].

Diagnosis of taenia infection and cysticercosis is based on the morphology and molecular characterization of the parasites [11,12]. Number and length of the large and small hooks, number and layers of testes, number of uterine branches, and structure of cirrus sac are important characteristics for morphological identification [1]. Usually, the prevalence of infection by C. tenuicollis was different according to animal geographical distribution and it had taken a high level in poor countries and could not be controlled among wild animals [13]. Numerous surveys on the prevalence have been reported in different parts of the world and Iraqi neighbor countries for $C$. tenuicollis. In Iraq, for the first time, it was isolated from the peritoneal cavity of sheep by Leiper [14]. The parasite was also recorded from the peritoneal cavity of sheep in north of Iraq [15], from slaughtered sheep in Basra [16], also the C. tenuicollis were isolated from sheep, goat, and cow in Erbil city [17], in another epidemiological study in Mosul and Diwania, the high prevalence rate of $C$. tenuicollis was recorded among slaughtered sheep [18]. While the low prevalence rate $(0.7 \%)$ of cysticercosis among sheep was reported in Dohuk [19]. The present work was conducted to determine the prevalence rate and molecular characterization (strain identification and genotyping) of C. tenuicollis among slaughtered sheep and goats in Sulaimani province for the first time.

\section{METHODS AND MATERIALS}

2.1 Study Area: This study was carried out in Sulaimani, Kurdistan, northeast of Iraq, which is located on the longitude (44.50-46.16) east and latitude (35.04 36.30) north. The samples (cysts) of Cysticercus tenuicullis (Fig.1) were collected from November 2017 to April 2018 at the new abattoirs of Sulaimani (Qragol). The total inspected animal was 13395 sheep and 693 goats, the samples collected from different organs including liver, lung, mesentery, and momentum, the cysts were preserved in sterile containers contain one volume (v/v) of $70 \%$ ethanol at $4{ }^{\circ} \mathrm{C}[20]$.

2.2 DNA extraction: The cysts of (T. hydatigena) were washed with phosphate buffer saline /or normal saline three times to remove the ethanol [21], the genome (total DNA) was extracted from the cyst by the modified Genomic DNA Extraction Kits (Miniprep Tissue) provided by (Geneaid, Korea), the extracted DNA preserved in the TE buffer at $-20^{\circ} \mathrm{C}$ until use [22].
2.2 PCR process: The amplification of a partial gene of the cytochrome oxidase one (CO1) gene was performed according to Nejad et al. [23]. Briefly, $50 \mu \mathrm{l}$ of a master mix containing 10-100 ng of DNA and 50 pmol of each primer; forward (5' TTT TTT GGG CAT CCT GAG GTT TAT 3') and reverse (5' TAA AGA AAG AAC ATA ATG AAA ATG 3), the Thermocycler (AB Biomed) was used: an entail step (denaturation) at $95^{\circ} \mathrm{C}$ for four minutes followed by 35 cycles at $94{ }^{\circ} \mathrm{C}$ for 45 seconds, $55{ }^{\circ} \mathrm{C}$ for the $30 \mathrm{~s}, 72{ }^{\circ} \mathrm{C}$ for $45 \mathrm{~s}$ and $72{ }^{\circ} \mathrm{C}$ for seven min, as a final extension step. The PCR product was detected on $1.5 \%$ ethidium bromide-stained agarose gel under UV illuminator (gel-documentation with the computerized system).

2.3 Nucleotide Sequence analysis: The PCR products purified from the residual of protein, RNA, primers, enzyme, salts, free nucleotides, to be ready for DNA sequencing. The PCR product was purified with a PCR product purification Kit (Amersham UK), The nucleotide sequencing was performed by the genetic analyzer after amplification of the partial gene (CO1) with forward and reverse primers separately to obtain forward and reverse sequences in CBAR Laboratory in Malaysia (Kualalampur Malaysia). The sequence analysis, multiple sequence alignment, sequence editing, and correction was done with genetic analyzing software Mega5 and Bioedit.

2.4 Statistical analysis: The epidemiological data analyzed with one way ANOVA and chi-square by statistical software SPSS version 17.

\section{RESULTS}

The overall prevalence rate in the current study of C. tenuicollis (Fig.1), among slaughtered animals (14088) including (13395) sheep and (693) goats was $352(2.63 \%)$ and $18(2.59 \%)$ respectively (Table 1). The statistically significant differences among sheep and goat were not observed $(\mathrm{P}>$ 0.05). Based on sex, also there were no significant differences $(\mathrm{p}>0.05)$ between male and female (Table 2).

The used primer in the current study was designed for identification of Taenia spp. [20], it has the ability to amplify a part of $C O 1$ gene of $E$. granulosus and $\mathrm{COl}$ gene of $T$. hydategena according to the molecular result of this study, some cysts were belonged to E. granulosus, which has same DNA molecular weight and they excluded in this study. Generally, all the cysts were identified as Taenia spp. and the PCR product of mt-CO1 yielded 446 bp (Fig. 2).

The partial nucleotide sequence of $(m t-C O 1)$ gene was submitted to the GenBank and recorded under accession number (MH638348), the result was corresponding with $T$. hydatigena. The multiple sequences alignment of the nucleotide with published references (JQ710588, KM032284, JN827307, and JQ710627) for $T$. hydatigena, the result shows that our finding is $100 \%$ identical with $T$. hydatigenia strain in Iran (JQ710588) and T. hydatigenia strain in Palestine (KM032284), 
while 99\% was similar with $T$. hydatigena isolated from Turkey (JN827307) and Iran (JQ710627) the alignment and differences of nucleotide were represented in (Fig.3).

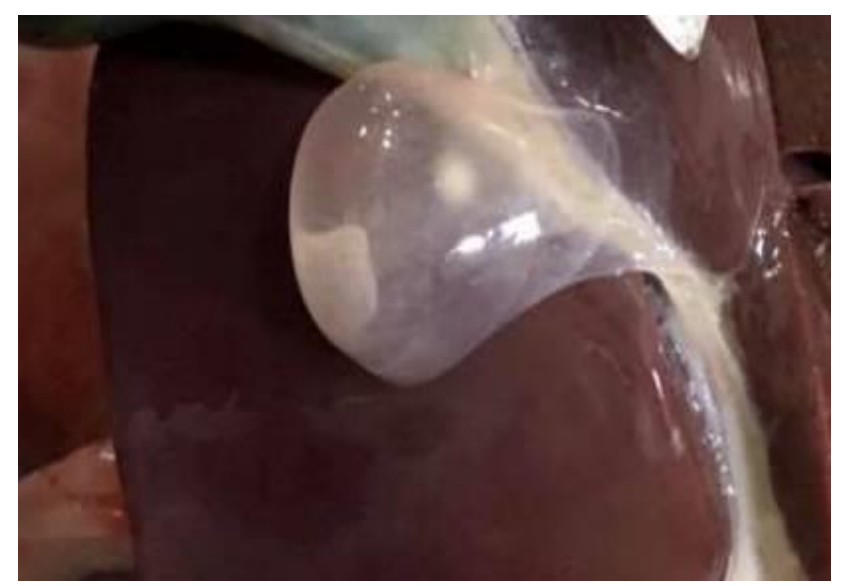

Figure (1): Full developed cyst (Cysticercus tenuicollis) on the liver surface of sheep.

Table (1): The prevalence rate of Cysticercus tenuicollis among slaughtered animals (sheep and goats) in Sulaimani province

\begin{tabular}{|c|c|c|c|c|c|}
\hline \multirow{2}{*}{ Hosts } & $\begin{array}{c}\text { Total } \\
\text { examined } \\
\text { animals }\end{array}$ & \multicolumn{2}{|c|}{$\begin{array}{c}\text { Negative } \\
\text { animal }\end{array}$} & \multicolumn{2}{c|}{$\begin{array}{c}\text { Positive } \\
\text { animal }\end{array}$} \\
\cline { 2 - 6 } & N0. & N0. & $\%$ & N0. & $\%$ \\
\hline Sheep & 13395 & 13043 & 97.37 & 352 & 2.63 \\
\hline Goats & 693 & 675 & 97.41 & 18 & 2.59 \\
\hline Total & 14088 & 13719 & 97.38 & 369 & 2.62 \\
\hline
\end{tabular}

$\mathrm{X} 2=0.0789 \quad \mathrm{p}$-value $=.778818 . \quad(\mathrm{p}>0.05)$

Table (2): The prevalence rate of Cysticercus tenuicollis among slaughtered animals (sheep and goats) according to the sex in Sulaimani province.

\begin{tabular}{|c|c|c|c|c|c|c|c|}
\hline \multirow{2}{*}{ Hosts } & \multirow{2}{*}{$\begin{array}{c}\begin{array}{c}\text { Total } \\
\text { examined }\end{array} \\
\text { N0. }\end{array}$} & \multicolumn{3}{|c|}{$\begin{array}{l}\text { Negative } \\
\text { animal }\end{array}$} & \multicolumn{2}{|c|}{$\begin{array}{c}\text { Positive } \\
\text { animal }\end{array}$} & \multirow{2}{*}{ 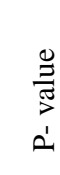 } \\
\hline & & & N0. & $\%$ & No. & $\%$ & \\
\hline \multirow{2}{*}{ Sheep } & 624 & $\mathrm{M}$ & 610 & 97.75 & 14 & 2.24 & \multirow{2}{*}{0.53} \\
\hline & 12771 & $\mathrm{~F}$ & 12433 & 97.35 & 338 & 2.65 & \\
\hline \multirow{2}{*}{ Goats } & 86 & $\mathrm{M}$ & 84 & 97.67 & 2 & 2.33 & \multirow{2}{*}{0.86} \\
\hline & 607 & $\mathrm{~F}$ & 591 & 97.36 & 16 & 2.63 & \\
\hline
\end{tabular}

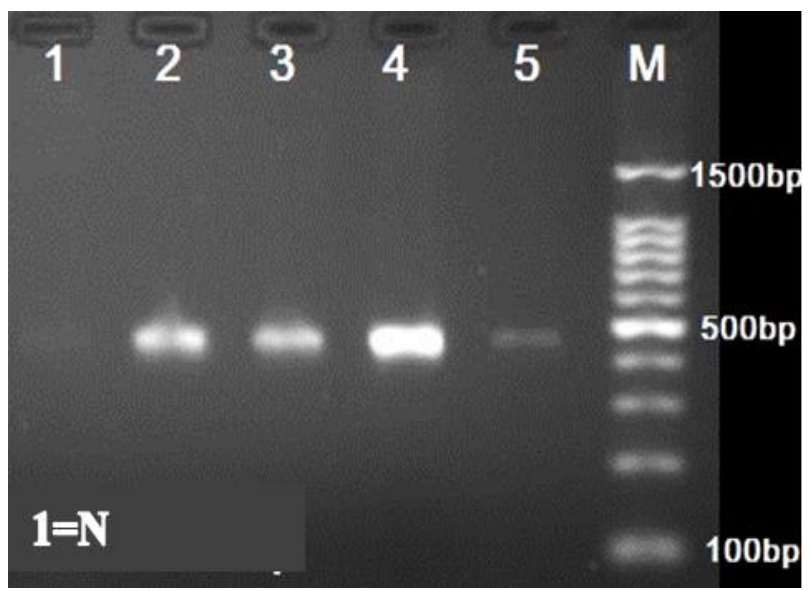

Figure (2): The Gel-electrophoresis of PCR product of mtCO1 gene shows DNA bands (446 bp). M: Marker, $1=$ Negative control

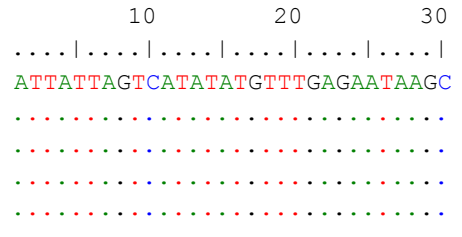

MH638348 Kurdistan JQ710588 . 1 Iran-go KM032284.1Palastin JN827307.1 Turkey JQ710627. 1 Iran

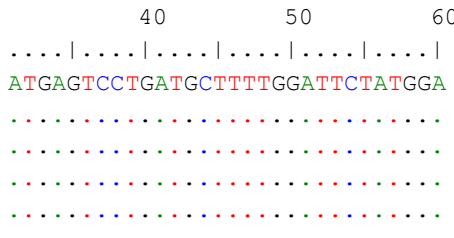

50

MH638348 Kurdistan JQ710588 . 1Iran-go KM032284.1Palastin JN827307.1 Turkey JQ710627. 1 Iran

$70 \quad 80$ 90

MH638348 Kurdistan JQ710588 . 1 Iran-go KM032284.1Palastin JN827307.1 Turkey JQ710627 . 1 Iran

MH638348 Kurdistan JQ710588. 1 Iran-go KM032284.1Palastin JN827307.1 Turkey JQ710627.1Iran

MH638348 Kurdistan JQ710588 . 1 Iran-go KM032284.1Palastin JN827307.1 Turkey JQ710627. 1 Iran

MH638348 Kurdistan JQ710588 . 1 Iran-go KM032284.1Palastin JN827307.1 Turkey JQ710627. 1Iran

MH638348 Kurdistan JQ710588. 1 Iran-go KM032284.1Palastin JN827307.1 Turkey J0710627.1Iran
TTATTATTTGCTATGTTTCAATAGTCTGT

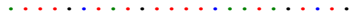

100

110

120

$\ldots|\ldots| \ldots|\ldots| \ldots|\ldots| \ldots \mid$

TTGGGTAGAAGTGTGTGGGGTCATCATATG

$\ldots \ldots \ldots \ldots \ldots \ldots \ldots \ldots$

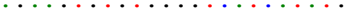

130

140

150

$\ldots \ldots \ldots \ldots \ldots \ldots \ldots$

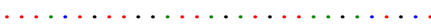

160

170

$\ldots . \ldots|\ldots| \ldots|\ldots| \ldots|\ldots|$

GTTTTTTAAGTCTGTCACTATGATTATA

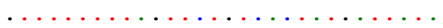

.

GGTGTGCCTACTGGTATAAAGGTGTTTACT

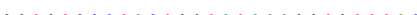

$\ldots \ldots \ldots \ldots \ldots \ldots \ldots \ldots \ldots$

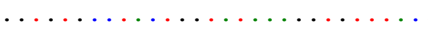

$\ldots|\ldots| \ldots|\ldots| \ldots \mid \ldots$ 


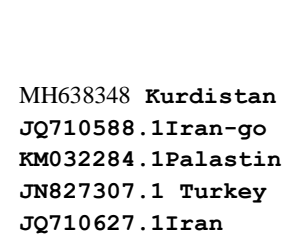

MH638348 Kurdistan JQ710588 . 1Iran-go KM032284.1Palastin JN827307.1 Turkey JQ710627 . 1 Iran

MH638348 Kurdistan
JQ710588.1Iran-go
KM032284.1Palastin
JN827307.1 Turkey
JQ710627.1Iran

MH638348 Kurdistan
JQ710588.1Iran-go
KM032284.1Palastin
JN827307.1 Turkey
JQ710627.1Iran

MH638348 Kurdistan JQ710588. 1Iran-go KM032284 . 1Palastin JN827307.1 Turkey JQ710627 . 1 Iran

MH638348 Kurdistan JQ710588 . 1 Iran-go KM032284.1Palastin JN827307.1 Turkey JQ710627.1Iran

Figure (3): Nucleotide sequences of partial $m t$-COX1 of $T$. hydatigena (MH638348) aligned with the published sequences of the T. hydatigena as a reference.

\section{DISCUSSION}

Cysticercus tenuicollis is a parasitic infection of herbivores caused by the larval stage (metacestode) of $T$. hydatigena with a global distribution, which has a veterinary, medical, and economic importance. The disease spreads through the contamination of water, soil, and vegetable with feces of infected dogs and other carnivores [24].

The present study recorded a low prevalence rate of $C$. tenuicollis among slaughtered animal sheep and goat $(2.6 \%)$, this finding is considered a low prevalence rate in comparison with the most studies that carried out in Iraq; Esa and Al-Aziz [25] in Basra, they recorded $40.55 \%$ and $26.25 \%$ infection rate among sheep and goats respectively. Moreover, Khadair [26] in Baghdad recorded a higher prevalence rate among slaughtered animals; $(14.22 \%)$ in sheep and $(16 \%)$ in goats. In the recent study for Haddawee et al. [27] in Karbala, they recorded a high prevalence rate of Cysticercus tenuicollis among animals in the different months and session, the prevalence rate was $(42.65 \%)$ in September,
$(45.57 \%)$ in August and $(30.91 \%)$ and $(28.40 \%)$ in October and November respectively, the authors explained the reason for the high prevalence rate of Cysticercus tenuicollis among sheep and goats may be due to inadequate knowledge and awareness about this disease among the Iraqi population and a lack of medical incinerator in the most slaughterhouses to collect and burn the infected organ and illegal slaughtering animals outside the abattoirs (on the street) makes difficult to control the disease, also the mostly infected organ (animal offal) will be accessed to the stray dogs due to improper management and a lack of medical incinerator, the national strategical plan to management and control of stray dog is required to reduce the infection with dog tapeworm E. granulosus and T. hydatidena [27].

While our result disagrees with Al-Saqur and Gorani [27] they recorded a lower prevalence rate of Cysticercus tenuicollis (1\%) among sheep. Although AlBakri [28] in Naynava recorded a low prevalence rate (2\%) of $C$. tenuicollis in sheep, which supports our finding. This variation may be due to the difference in management practice, environmental factors, also the knowledge about the disease and separating dogs from sheep and goats, also frequently cleaning of the domestic animal house has a direct effect on reducing the infection.

The significant differences in $C$. tenuicollis infection between sheep and goat were not observed, this finding disagrees with some studies [25, 29], they recorded a higher infection rate of $C$. tenuicollis among sheep than in goats, while Rdfar et al.[2] recorded $26.7 \%$ in sheep and, $27.9 \%$ in goats the infection rate among goats is slightly higher than in sheep, the author stated that grazing behavior and management can be considered as the major reasons, also Nejad et al. [23] stated that the high prevalence rate among sheep due to the immune system of sheep, the immunity of the sheep is developed quickly in comparison with goat's immune system and this immunity regulate and limited the parasite infection. The prevalence rate of $C$. tenuicollis among male and female relatively have the same prevalence rate of infection this may be due to both male and female have the same chance to get an infection after ingestion of the egg during feeding of contaminated food or water. In the present study, the significant differences of infection rates were not observed between a male and female of sheep and goat, while the females will be more susceptible this result agreed with [25] the slight differences of infection rate with $C$. tenuicollis between male and female may be due to physiological and hormonal effect. The inspection of meat for $C$. tenuicollis is more difficult if cysts are degenerated or low developed, the meat inspection procedure has a probability to detect about $20-50 \%$ of actual infected animals [30]. The molecular-based methods are not alternative of inspection methods for cyst detection, while the combination between direct inspection and DNA markers are important to understanding the nature and origin of cysts [31]

The morphological and biochemical markers are helpful for species and strain identification of Taenia spp. while the molecular and DNA markers are more accurate and dependable for molecular epidemiology study [32]. The 
DNA marker and molecular characterization are valuable for species and strain identification of Taenia species $[33,34]$. The alignment and blast of the present sequences which deposited in GenBank (MH638348) shows that $100 \%$ similar with (JQ710588) in Iran [35] and with (KM032284) in Palestine while 99\% similar with (JN827307) in Turkey and (JQ710627)in Iran, this may be due to close contact of the Kurdistan Region of Iraq with Iran and Turkey and they relatively have the same climate, culture, and lifestyle also the majority of domestic animals were imported from Iran and Turkey to Kurdistan-Iraq [36, 37].

Different molecular markers have been developed for molecular characterization and species, strain identification of Taenia, the most common approaches are DNA sequencing, restriction enzyme fragment length (RFLP), PCR-linked RFLP, AFLP, and PCR-RFLPs of the rDNA internal transcribed spacers 1 and 2 (ITS1 and ITS2) [12]. In the current study the partial cytochrome oxidase gene (CO1) which is a mitochondrial DNA was studied, the mitochondrial DNA sequences have been used widely in world as a genetic and DNA marker to evaluate the genetic population structure, the DNA sequencing of met-CO1 is useful for evolutionary and relationship and also it can be used for species and strain identification of the Taenia and another worm.

\section{CONCLUSION}

Our result concludes that the prevalence rate of $C$. tenuicollis among sheep and goat in Kurdistan Region of Iraq is $(2.6 \%)$, which is lower than those of most Iraqi neighbor countries.

The amplification of $\mathrm{COl}$ gene with the current primer is not dependable to discriminate hydatid cyst (HC), which is caused by dog tapeworm Echinococcus granulosus and $C$. tenuicollis, DNA sequencing and accurate methods for species and strain identification of Taenia worm are required.

Molecular techniques are not an alternative to direct meat inspection, but the combination of both methods will be the most valuable for confirmation of $C$. taenicollis infection.

\section{ACKNOWLEDGMENT}

The authors would like to thank Sulaimani abattoir veterinarian and administration staff and special thanks for the Technical College of Health and Research center of Sulaimani Polytechnic University for their support and facilities.

\section{REFERENCES}

[1] T. Kassai. "Veterinary Helminthology," Butterworth-Heineman Publishing, Oxford, UK. 1999

[2] M. H. Rdfar, S. Tayalli, and M. Jalazadeh, "Prevalence and morphological characterization of Cysticercus tenuicollis (Taenia hydatigena cysticerci) from sheep and goats in Iran," Vet. Archiv.75:469-476. 2005

[3] G. H. Michigan, Thin -necked Bladder warm, Cysticercosis. http:/www. Michigan DNR Wildlife Disease Laboratory. 2009
[4] K.C. Smith, T. J. Parkinson, S. E. Long, "Abattoir survey of acquired reproductive abnormalities in ewes," Vet. Rec., 144: 491-496. 1999

[5] E. J. L. Soulsby, "Helminths, arthropods, and protozoa of domesticated animals," $7^{\text {th }}$ ed. Baillir Tindall, London, pp.113. 1982

[6] OIE, "OIE Terrestrial Manual," Chap. 2.1.4. In: Echinococcosis/Hydatidosis, Paris, pp 175-189. 2008

[7] S. M. A. Abidi, W. A. Nazami, P. Khan, M. Ahmad, M. Irshadullah, "Biochemical characterization of Taenia hydatigena cysticerci from goats and pigs," Journal, Helminthology, 63, 333-337. 1989

[8] J. Kaufmann, "Parasitic infections of domestic animals," A diagnostic manual Birkhauser Verlag, Basel, Schweiz. 1996

[9] R.C.A. Thompson, A. J. Lymbery, "Echinococcus and hydatid disease". $1^{\text {st }}$ ed. Wallingford.CAB International. 1995

[10] D. C. Blood, O. M. Radostitis, J. H. Arundle, C. C. Gay, "Veterinary medicine," $7^{\text {th }}$ ed.Baillier Tindall, London.pp.608. 1989

[11] D. P. McManus, "Molecular discrimination of taeniid cestodes," Parasitology International, vol. 55, pp. 531-537. 2006

[12] L. M. N. Gonzalez, E. Villalobos, Montero "Differential molecular identification of Taeniid spp. and Sarcocystis spp. cysts isolated from infected pigs and cattle," Veterinary Parasitology, 142, 1-2, pp. 95-101. 2006.

[13] H. Budka, S. Buncic, P. Colin, J. D. Collin, C. Ducrot, J. Hope, J. Johnston, G. Klein, H. Kruse, E. Lucker, S. Magnino, A. Martinez-Lopez, R.. L. Maijala, C. Nguyen-The, "Opinion of the Scientific Panel on Biological Hazards on a request from the Commission related on Revision of Meat Inspection Procedures for Lambs and Goats," EFSA Journal, 54:1-49.2004.

[14] J. W. G. Leiper, "Animal parasites and their control Report to the government of Iraq," Rome, F. A. O., No. 610. 1957

[15] P. B. Mathur, M. A. Karim, F. Al-Fathy, "Observation on the incidence of some important helminths in sheep in Northern Iraq-working Paper," UNDP/FAO, Iraq, 71,542. 1974

[16] I. M. Al-Saqur, A. M. A. Al-Gorani, "Larval stages of cestodes in the Viscera of sheep". Journal of Biology, Science, Research., 18: 33-41. 1987

[17] A. L. Molan, I. S Saed, "A survey of hepatic and pulmonary helminths and Cestodes larva stage in goats and cow of Arbil province," Journal of Agriculture and Water Resource, 2:105114. 1988.

[18] H. AL-Mayali, "The incidence and pathology of Cysticercosis in sheep naturally infected with Cysticercus tenuicollis larvae," College of Education University of Al-Qadisiya, 4:19- 35. 2005.

[19] N. M. Ghaffar, "Prevalence of hydatidosis in livestock slaughtered at Dohok abattoir of Kurdistan Region of Iraq," M.Sc. Thesis. College of Veterinary, Medicine University of Dohuk. 2008

[20] J. Bowles, D. Blair, D.P. McManus "Genetic variants within the genus Echinococcus identified by mitochondrial DNA sequencing," Molecular and Biochemistry, Parasitology 54, pp. 165-173. 1992

[21] D. Bhattacharya, A. K. Bera, B. C. Bera, A. Maity and S. K. Das "Genotypic characterization of Indian cattle, Buffalo and sheep isolate of E. granulosus," Veterinary, Parasitology, 143; pp. 371374. 2007.

[22] A. A. Hama "Comparison Study to Evaluate Efficiency of Three DNA Extraction Method from Hydatid Cyst," Journal of Garmian University, 2 (special), 624-629, 2015.

[23] M. R. Nejad, M. Roshani, Lahmi and F.E. Mojarad "Evaluation of four DNA extraction methods for the detection of Echinococcus granulosus genotype," Journal of Gastroenterology and Hepatology, FBB., 4 (2), pp. 91-94, 2011.

[24] A. E. Utuk, F. C. Piskin, "Molecular detection and characterization of goat isolate of Taenia hydatigena in Turkey," Scientific World Journal, 962,732, 2012. doi:10.1100/2012/962732.

[25] I. M. Essa, S. A. Al-Azizz, "Studies on cysticercus tenuicollis collected from slaughtered sheep and goats in Basrah abattoir, Iraq," Egyptian Journal of Experimental, Biology (Zool.),7(2):343 - 347,2011.

[26] A. A. Khudair, "Study on the epidemiology of the larval stage Cysticercus tenuicollis of the cestode Taenia hydatigena in sheep and goats," M.Sc. Thesis, Baghdad University, College of Veterinary Medicine, pp. 58. 1998.

[27] R. H. Haddawee, I.M. Sulbi and Z.F. Abbas "Prevalence of Cysticercus tenuicollis in slaughtered sheep and goats by 
season, sex, age, at Karbala abattoir, Iraq," Scientific. Journal. Medical. Research. 2 (5): 52-56. 2018.

[28] I. M. Al-Saqur, A. M. A. Al-Gorani, "Larval stages of cestodes in the Viscera of sheep," Journal of Biology Science and Research, 18: 33-41. 1987.

[29] H. S. Al-Bakri "Prevalence of Tenuicollosis Among Livestock Slaughtered at Ninevah,” vol. 2, pp. 30-39, 2012.

[30] OIE. "Cysticercosis, Manual of the standard of diagnostic test and vaccine," OIE, terrestrial manual.2008.

[31] A. Lavikainen, V. Haukisalmi, G. Deksne, K. Holmala, M. Lejeune, M. Isomursu, P. Jokelainen, A. Näreaho, J. Laakkonen, E. P. Hoberg, A. Sukura, "Molecular identification of Taenia spp. in the Eurasian lynx (Lynx lynx) from Finland," Parasitology, vol. 140, no. 5, pp. 653-662, 2013.

[32] A. A. Hama, O. H. Shareef, "Morphological and morphometric study of Echinococcus granulosus (metacestode) in Sulaimani Province / Kurdistan," Kurdistan Journal of Applied Research vol. 7684, no. 1, pp. 1-6, 2016.

[33] Z. I. Hassan, A. A. Meerkhan, B. Boufana, A. A. Hama, B. D Ahmed, W. M. S. Mero, S. Orsten, M. Interisano, E. Pozio, A. Casulli, "Two haplotype clusters of Echinococcus granulosus sensu stricto in northern Iraq (Kurdistan region) support the hypothesis of a parasite cradle in the Middle East," Acta Tropica, vol. 172, no. April, pp. 201-207, 2017.

[34] A. A. Hama. Z. I. Hassan, S. M. W. Mro, M Interisano, B. Boufana, A. Casulli, "A Morphologically Unusual Echinococcus granulosus (G1 Genotype) Cyst in a Cow from Kurdistan - Iraq," Epidemiology Open Access, vol. s2, pp. 2-4, 2015.

[35] S. Rostami, R. Salavati, R. N. Beech, Z. Babaei, M. Sharbatkhori, M. R. Baneshi, E. Hajialilo, H. Shad, M. F. Harandi, "Molecular and morphological characterization of the tapeworm Taenia hydatigena (Pallas, 1766) in sheep from Iran," Journal of Helmintholgy, 89 (2), pp. 150-157, 2015.

[36] A. A. Hama, W. M. S. Mero, and J. M. S. Jubrael, "First Report of Sheep Strain in Kurdistan-Iraq," Second international conference. Bali (Indonesia), (4):.41-44.2012.

[37] W. M. S. Mero, J. M. S. Jubrael, A. A. Hama, "Prevalence of Hydatid Disease Among Slaughtered Animals in Slemani Province/ Kurdistan-Iraq," Journal of University of Zakho 1, (2) pp. 1-5. 2013. 